\title{
A proof-of-concept framework for the preference elicitation and evaluation of health informatics technologies: the online PRESENT patient experience dashboard as a case example
}

\author{
Emmanouil Mentzakis ${ }^{1}$, Daria Tkacz ${ }^{2}$ and Carol Rivas ${ }^{3^{*}}$ (I)
}

\begin{abstract}
Background: Constrained budgets within healthcare systems and the need to efficiently allocate resources often necessitate the valuation of healthcare interventions and services. However, when a technological product is developed for which no market exists it is a challenge to understand how to place the product and which specifications are the most sought after and important for end users. This was the case for a dashboard we developed, displaying analyses of patient experience survey free-text comments.

Method: We describe a customisation and evaluation process for our online dashboard that addresses this challenge, using a Discrete Choice Experiment (DCE). We were not interested in the exact content of the dashboard, which was determined in previous stages of our larger study, but on the availability of features and customization options and how they affect individuals' purchasing behaviours.

Results: Our DCE completion rate was 33/152 (22\%). Certain features were highly desirable - the search function, filtering, and upload own data - and would contribute significant added value to the dashboard. Purchasing behaviour was dependent on the dashboard features, going from a 10 to $90 \%$ probability to purchase when we moved from a baseline to a fully-featured dashboard.

The purchasing behaviour elicited in this study assumes individuals already have buy-in to the online dashboard, so we assessed only how the various features of our dashboard influence the probability of purchasing the product. Results were used to inform development of a generic checklist of desirable healthcare dashboard features as well as to refine the dashboard itself. Our study suggests the development of the online dashboard and its roll-out in the market would result in a positive net benefit in terms of utilities. The cost-benefit analysis offers a lower bound estimate of the net benefit as it does not acknowledge or incorporate non-monetary benefits that would result from the use of the online dashboard, such as from improved healthcare management.

(Continued on next page)
\end{abstract}

* Correspondence: crivas@ucl.ac.uk

${ }^{3}$ Social Science Research Unit, Department of Social Science, University

College London (UCL), 18 Woburn Square, London WC1H ONR, UK

Full list of author information is available at the end of the article

C C The Author(s). 2020 Open Access This article is licensed under a Creative Commons Attribution 4.0 International License, which permits use, sharing, adaptation, distribution and reproduction in any medium or format, as long as you give appropriate credit to the original author(s) and the source, provide a link to the Creative Commons licence, and indicate if changes were made. The images or other third party material in this article are included in the article's Creative Commons licence, unless indicated otherwise in a credit line to the material. If material is not included in the article's Creative Commons licence and your intended use is not permitted by statutory regulation or exceeds the permitted use, you will need to obtain permission directly from the copyright holder. To view a copy of this licence, visit http://creativecommons.org/licenses/by/4.0/. The Creative Commons Public Domain Dedication waiver (http://creativecommons.org/publicdomain/zero/1.0/) applies to the data made available in this article, unless otherwise stated in a credit line to the data. 
(Continued from previous page)

Conclusion: DCEs can be successfully used to inform development of an online dashboard by determining

preferences for particular features and customisation options and how this affects individuals' purchasing

behaviours. The process should be transferable to the development of other technologies.

Keywords: Discrete choice experiment, DCE, Online dashboard, Technology development, Health informatics, Healthcare, Cost-benefit analysis, Willingness-to-pay, Ranking, Checklist

\section{Background}

Constrained budgets within healthcare systems and the need to efficiently allocate resources often necessitate the valuation of healthcare interventions and services. For economists, markets provide the main mechanism through which the true value of a good is revealed. When someone chooses to purchase a good/service, this implies a preference, whereby the utility (or satisfaction) the person derives from their purchase is at least as big as the cost/price they had to pay. However, what happens when preferences need to be considered and understood for a good/service for which there is no current market? This is the problem we had when developing a new patient experience online dashboard. Our dashboard involved novel use of text analysis and text analytics of national health service patient experience survey free-text comments in a way that could drive healthcare improvements. For such non-market goods, two further dimensions need consideration. First, a market could eventually exist but often the developer requires some prior insight of the market structure so as to place their product correctly. Second, a product could have an impossibly large number of different specifications, and choosing which to supply, i.e. which features are the most sought after and important for eventual users, requires prior intelligence during the development stage. Such information is not just important for market placement, but also in order to develop a system that best satisfies its users, which was a core ethos of the PRESENT study [1].

In the larger PRESENT study we had sought to determine these factors from a literature review, survey of relevant potential end users of the dashboard, a workshop and interviews. But the review findings were limited, due to a lack of previous work in the field of evaluations of healthcare dashboard feature preferences, the survey produced comments on what respondents had personal experience of, rather than what they desired, and the qualitative data from the workshops and interviews was a retrospective co-construction between researchers and participants [2].

We believed that Discrete Choice Experiments (DCEs) would provide a different way of getting at the information, that would satisfy all our requirements and that would allow elicitation of monetary values not only of the product but of each individual feature. DCEs are based on primary experimental data and provide researchers with the ability to place individuals in controlled environments (situations) and investigate issues in isolation without potential confounding biases. DCEs are founded on the consumer behaviour and preferences theory of Lancaster [3] and Rosen [4] and draw on subconscious cognitive processes. They postulate that utility is not derived from the consumption of a good per se, but from the characteristics this good possesses. Thus, the characteristics of a good determine its value, and differences in the characteristics result in different degrees of desirability for the individual. In essence, the researcher describes a good in terms of its features, with various combinations of features available as if they were multiple different hypothetical products. Potential users are then asked which product version they would purchase if they were given the chance. The underlying intuition is that the user will consider the features of the different products presented to them and will trade-off among them, as well as the specific price for each product. They will then choose to purchase (or rather state their intention to purchase) the one they deem the most attractive or desirable given the price. DCEs so far have seen applications in many fields, among others including marketing, environmental, economics and health [5-7], and have been recommended in the evaluation of health technologies $[8,9]$, but to our knowledge they have not been used to develop healthcare technologies.

This paper sets out to describe a customisation and evaluation process for an online/software dashboard that was developed as part of an online toolkit (the 'PRESENT' study toolkit). Specifically, the DCE provides feedback on market placement and calculates how much individuals are willing-to-pay for each of the features of the online dashboard and how likely they are to purchase or not purchase a dashboard given its features. This knowledge was useful for determining the final design of the PRESENT dashboard, particularly when it came to making choices between different conflicting information from the prior review, survey and qualitative work, which we summarise further later in this paper. The context and methodology are directly applicable to the development and evaluation of any physical or electronic product and service and this paper aims to also 
serve as the introduction of such an approach in the product development and evaluation of health care technology more generally. Our work has been welcomed by our networks as much needed.

\section{Prior work and context}

UK healthcare policy foregrounds the patient's perspective on quality of care. The PRESENT study was developed to display results from the successful National Cancer Patient Experience Survey (CPES). Since 2010 this has been sent over a 3-month period each year to all patients treated for cancer as in-patients or day cases in NHS Trusts in England. But there has been no way of systematically, efficiently and usefully analysing and reporting the free-text responses in this and other similar surveys, despite this being a recognised need. The PRESENT project therefore used rule-based information retrieval [10] to structure CPES free-text comments and Python programming language (https://www.python.org/ ) to display results and text analytics in a summary visual format in a digital dashboard display that could be drilled down to the original free-text.

A dashboard approach was chosen because of its popularity in healthcare. In 2009, the NHS Connecting for Health initiative, now incorporated within The Health and Social Care Information Centre (http:// webarchive.nationalarchives.gov.uk/20130502102046/ http://www.hscic.gov.uk/aboutus), began the Clinical Dashboards Programme. This was an attempt to make dashboard development more accessible to healthcare professionals as a useful way of summarising healthcarerelevant data. But its recommendations do not appear to have been based on domain-specific considerations that incorporated patient views and nor do they appear to have been informed by empirical work on healthcare dashboard usability and design considerations. Moreover this programme was so flexible that it led to very divergent design approaches that often breached Gestalt design principles [11]. Good dashboards should tailor their designs to specific end user requirements without breaking these principles. Dowding and colleagues [12], in a 2015 review of the use of clinical and quality dashboards in healthcare environments, found some indication of their effectiveness in improving patient outcomes. However these authors stated that further high quality detailed research studies were needed to confirm this and to establish guidelines for dashboard design for healthcare settings. They also noted heterogeneity in the design of the dashboards they evaluated, for example concerning the use of text or graphs, colours, and how information was presented to users.

The PRESENT study therefore aimed to develop a dashboard that could drive service improvements whilst maintaining Gestalt principles, and to provide guidelines on healthcare dashboard design. To do so, we used an interdisciplinary approach that maintained the patient voice in the data, whilst producing themes and displays that were meaningful to staff in terms of healthcare improvement possibilities, and concordant with programming and web design principles. The study was divided into three stages. The first stage (see Table 1 for findings) led to development of a list of potential attributes of a dashboard, which was refined in subsequent stages of the study and used for the DCE. This stage involved a scoping literature review on clinical digital toolkit design which found little relevant literature; what there was, focused on design principles rather than applied use. It also included a stakeholder dashboard scoping survey, disseminated through relevant healthcare networks and websites; $n=33$ of the 35 respondents were healthcare professionals. From this survey we identified several attributes additional to those determined from the review (Table 1).

In the second study stage our focus was on developing several prototype dashboards based on results from stage one. The prototypes were discussed with 34 stakeholders in patient experience (patients, healthcare staff and third sector) in our six workshops ( $n=4-9$ per group). Modally, these were female, in their 50s, and they self-reported as from a crosssection of ethnic groups; Table 2. Different types of stakeholder had different understandings of dashboard usage. In the first workshops we proposed that we would produce more than one final dashboard, to represent different user settings, but it rapidly became clear that potential end-users wanted one system with different layers of access depending on who they were. This is in keeping with CPES; the comments in this survey cut across primary and secondary care of all types. The focal feature was the patient experience and different end uses could be satisfied simply by including filters and search functions within one dashboard. The prototypes were further explored in semi-structured interviews with purposively selected workshop participants (those across the three main stakeholder groups who diverged from the main group or had strong viewpoints). Interview theme saturation was reached at $n=12$ participants.

From the workshops and interviews we determined data sharing issues, expectations around machine learning accuracy and patient experience survey sampling biases as critical topics for further debate and consideration before patient feedback data can be fully and optimally used. The workshops and interviews led to amendments to our prototype, such as level of granularity and filtering (see Fig. 1) as well as the decision to have one prototype suitable for all, rather than multiple versions. 
Table 1 Summary of the key features healthcare dashboards and toolkits should incorporate according to our prior literature review and our survey of healthcare professionals

\begin{tabular}{|c|c|}
\hline Feature category & Examples \\
\hline Access & $\begin{array}{l}\text { minimising workload burden, e.g.: } \\
\text { - easily digested summaries (s) } \\
\text { - integrated into an already existing system / constantly in sight } \\
\text { - registration absent or clear and short } \\
\text { engaging homepage with clear statement of value } \\
\text { real-time access e.g. during clinics } \\
\text { access to the raw data (s) }\end{array}$ \\
\hline Flexibility and individualisation & $\begin{array}{l}\text { personalisation features } \\
\text { alerts and reminders } \\
\text { information pins } \\
\text { dynamic movement of elements of the dashboard to fit around the user's focus and workflow } \\
\text { ensure reactive to different devices } \\
\text { layout logic and route that anticipates the user's workflow } \\
\text { a combination on one computer screen of high-level overviews to highlight problem areas and benchmarks of re- } \\
\text { gional and national performance of choice }(s) \\
\text { the potential to upload and incorporate their own quantitative data }(s)\end{array}$ \\
\hline Use of images and videos & $\begin{array}{l}\text { informative rather than decorative images, that reflect the user's demographic profile videos to instruct on how to } \\
\text { use the dashboard }\end{array}$ \\
\hline Chart types & $\begin{array}{l}\text { line and bar charts - well labelled- for analysing relationships, tables for extracting specific values and complex } \\
\text { tasks; function to choose graphic type or table } \\
\text { including reference data points such as national averages for easier interpretation } \\
\text { several graphs on one screen }\end{array}$ \\
\hline Data interrogation & $\begin{array}{l}\text { ability to filter the data in real-time and to sort it by any level and quality indicator; filter parameters need to be } \\
\text { practical and clearly defined and aligned with the user's work } \\
\text { feedback that the page has changed after filtering } \\
\text { search box for interrogating the data / drop-down list or dictionary of suggested search terms }\end{array}$ \\
\hline Print and export & the option to print information, download data outputs \\
\hline Community features & $\begin{array}{l}\text { patient stories and other narrative videos } \\
\text { forum, chat room or similar community feature signposting to other sources of information and support }\end{array}$ \\
\hline Governance & $\begin{array}{l}\text { security and privacy prioritised } \\
\text { good data reliability (s) }\end{array}$ \\
\hline $\begin{array}{l}\text { Offering recommendations and } \\
\text { solutions }\end{array}$ & $\begin{array}{l}\text { highlighting problems, but also offering recommendations or solutions } \\
\text { a simple predictive tool (s) }\end{array}$ \\
\hline
\end{tabular}

Items marked (s) were identified from our survey of healthcare professionals. All other items were identified from our review

The DCE was a part of our final proof-of-concept and validation stage of the main study and was followed by amendments to our prototype and then walkthrough techniques, to explore usability and implementation of the dashboard.

The research questions for the DCE were:

1. How much are individuals willing-to-pay for each of the features of the online dashboard?

2. Which features are monetarily the most desirable, as a proxy for practical desirability in use by health services managers within cancer care?

3. How likely are they to purchase or not purchase a dashboard given its features?

\section{Methods}

In conducting our DCE a number of steps needed attention so as to maximize the quality of responses and results and to provide answers to our research questions. These steps are now considered.
Determining attributes and levels for our DCE

In this section we describe how we determined the attributes and levels for our DCE.

i. First, the features (called attributes) of the good in question need to be selected, that will be included in the DCE. Commonly these attributes are based on expert knowledge and discussion, literature reviews and often intuition. In the PRESENT study they were developed from our stage one and two work and a key reason for deciding on the DCE was to answer research question 2 (see above) and triangulate responses with those from other parts of the study.

ii. A price attribute may also be included in the DCE for willingness-to-pay (WTP) calculations, in other words, to determine the price one is willing to pay for a specific feature (research question 1).

iii. Subsequently, for each attribute, the number of levels of detail and the levels themselves have to be chosen. They should be realistic and cover the range 
Table 2 Breakdown of pre-DCE workshop discussants by characteristics

\begin{tabular}{|c|c|}
\hline Stakeholder role $(n=34)$ & $\begin{array}{l}\text { Number } \\
(\%)\end{array}$ \\
\hline $\begin{array}{l}\text { Patient (predominantly cancers and in one group multiple sclerosis, but also heart disease; diabetes mellitus, heart and retinopathy; } \\
\text { non-cancer muscular or skeletal conditions and dementia; sickle cell disease; mental health; sarcoma) }\end{array}$ & $14(41)$ \\
\hline Carer & $1(3)$ \\
\hline Consultant/specialist & $1(3)$ \\
\hline GP & $1(3)$ \\
\hline Nurse & $3(9)$ \\
\hline Quality team member & $0(0)$ \\
\hline Variety of commissioning roles & $2(6)$ \\
\hline Budget holder & $0(0)$ \\
\hline Non-executive director NHS patient and public engagement lead & $1(3)$ \\
\hline Policy-maker & $0(0)$ \\
\hline Academic & $2(6)$ \\
\hline Other (an advocate for dementia patients; patients who were also carers/budget holders/academics) & $7(20)$ \\
\hline Did not say & $2(6)$ \\
\hline \multicolumn{2}{|l|}{ Gender } \\
\hline Male & $8(23)$ \\
\hline Female & $23(68)$ \\
\hline Did not say & $3(9)$ \\
\hline \multicolumn{2}{|l|}{ Ethnicity } \\
\hline White British & $19(58)$ \\
\hline Any other white background & $3(9)$ \\
\hline Mixed/multiple ethnic groups: white and black Caribbean/African & $2(6)$ \\
\hline Asian/Asian British: Indian & $1(3)$ \\
\hline Asian/Asian British: Chinese & $1(3)$ \\
\hline Any other Asian background & $2(6)$ \\
\hline Black: African & $1(3)$ \\
\hline Black: Caribbean & $1(3)$ \\
\hline Did not say & $3(9)$ \\
\hline Ages & $\begin{array}{l}\text { Year of } \\
\text { birth }\end{array}$ \\
\hline Minimum & 1938 \\
\hline Maximum & 1988 \\
\hline Mean & 1965 \\
\hline Mode & 1984 \\
\hline
\end{tabular}

of potential values within which an individual's preferences would fall. For example, for the attribute 'search functionality', three levels might be: no search; search by one fixed variable; search by selecting from a menu of suggested variables.

Our stage one and two work identified 21 potential attributes that were relevant to the prototype dashboard design that we had developed. Through discussion within the research team, and further co-design work - exploring the dashboard and attributes list in a workshop with our advisory group and through their networks within the DCE work - the number of attributes was reduced down to 10 key features of a healthcare dashboard.

\section{Experiment design for our DCE}

By combining one level of each attribute for all attributes, we created a complete specification of the product 


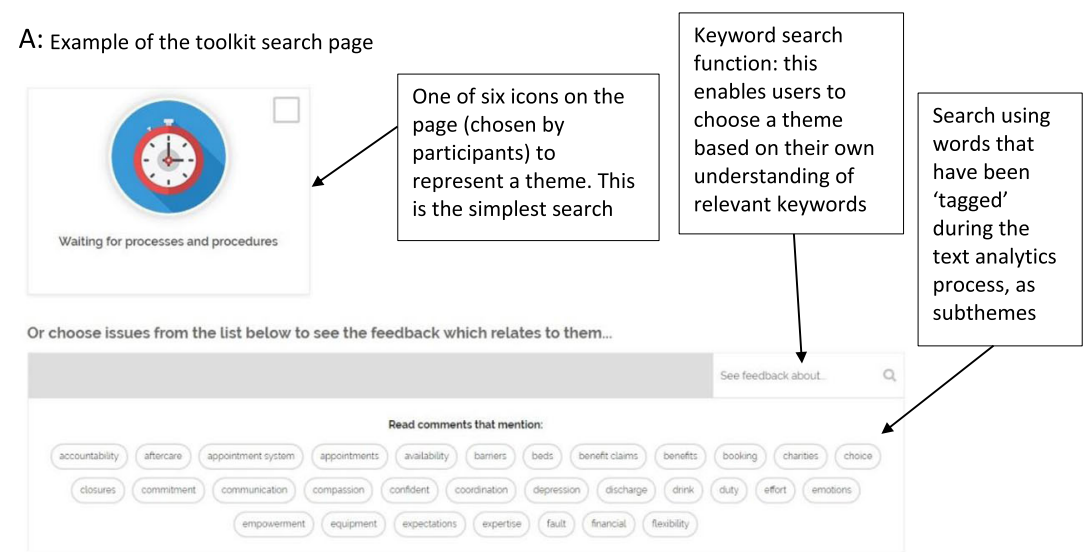

B: The demographic filtering on the dashboard as finalised after the DCE

\section{Hospital 17}

Health Board 1

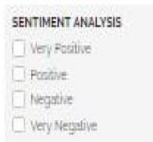

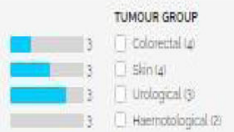

Nore

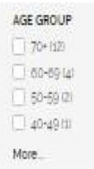

More.

C: The summary page for an overview of the text analytics
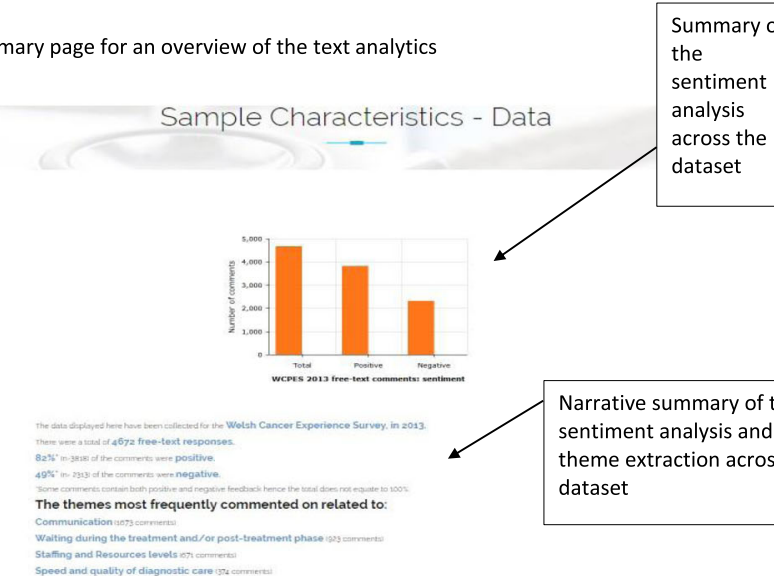

Summary of the sentiment analysis across the dataset

D: A draft graphical representation of the data produced from the text analytics work

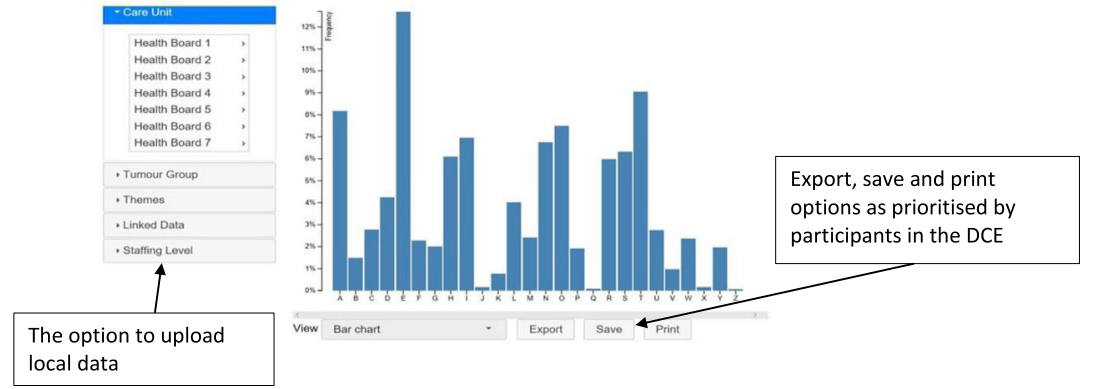

Fig. 1 (See legend on next page.) 
(See figure on previous page.)

Fig. 1 Details from our toolkit in development. a Example of the toolkit search page. $\mathbf{b}$ The demographic filtering on the dashboard as finalised after the DCE. c The summary page for an overview of the text analytics. Narrative summary of the sentiment analysis and theme extraction across the dataset. $\mathbf{d}$ A draft graphical representation of the data produced from the text analytics work. The option to upload local data. Export, save and print options as prioritised by participants in the DCE

with alternatives. In a DCE these alternatives are then placed in groups of two or three to create the scenarios (or choice sets) that are presented to respondents and that form the basis of the questionnaire. The number of alternatives and choice sets depends on the number of attributes and levels $[5,13,14]$. The procedures to determine which attribute levels to combine into alternatives and which alternatives to be placed together in choice sets is guided by experimental design principles that ensure efficiency and identification of intended effects (for more information on this see $[13,14])$. For the online dashboard we had 8 attributes of 2 levels and 2 attributes of 4 levels, which required each respondent to make choices for a minimum of 15 choice sets of two alternatives each (i.e. 15 pairwise sets of two alternative hypothetical dashboards). Figure 2 presents an example of a choice set that was used in the survey.

Draft DCE pages were piloted online, using a questionnaire design, on three healthcare professionals who fitted the profile of potential users (health service managers and decision-makers), to help with the design, wording and presentation of the survey. We also elicited from potential users the maximum they would be willing to pay for a desired dashboard, and whether this should be costed as an individual or team purchase. Changes were implemented, such as avoiding repetitive wording and simplifying the comparisons, and further feedback sought via cognitive interviews (in the questionnaire development use of the term) with two stakeholders who were academic clinicians with decision-making responsibilities [1]. These 'think aloud' interviews led us to simplify the introductory pages and add screenshots of the dashboard that users could check at any time as a reminder. The number providing feedback was less than we had hoped for (our aim was 15 overall), due to project time constraints. However various studies have shown that 5-15 participants of any demographic makeup who are able to use technology are sufficient to find most potential issues with a technology and we achieved the bottom end of this range [15]. The final list of attributes and levels selected for the DCE is provided as Supplementary information. The cognitive burden of such choices was deemed large in feedback and a number of steps were taken to reduce it and render the DCE more manageable for respondents. First, we increased the number of alternative dashboards within each choice set to three. This reduced the number of choice sets required per respondent to eight. Second, a partial profile design was implemented, where only a subset of four attributes was allowed to vary among the three alternatives in each choice set but with a different subset of attributes across different choice sets. This convenience and discount in cognitive burden comes however with the cost that each respondent must see a larger number of choice sets. Using one of the features of our experimental design software, three different versions of this basic design were created that varied the combination of attributes and levels presented to individuals. This increased the number of choice sets that were evaluated by respondents to increase coverage of the full factorial, more accurately identify trade-offs and improve the overall efficiency of the experimental design. As such, three Defficient fractional factorial partial-profile designs with eight choice sets each and three alternatives per choice set were generated. Each respondent was randomly assigned to one of the three versions.

Forcing individuals to indicate their preferred alternative out of the three in each choice ensures that individuals trade off between the attributes of the alternatives without the possibility of choosing to decline the purchase. However, this makes it impossible for the researcher to elicit true purchasing behaviour given that the corresponding real-word choice would be first whether to purchase a dashboard service and subsequently which version one would like. As such, we implemented a two-stage elicitation strategy where individuals were first asked which of the three alternatives they prefer and subsequently whether they would rather keep their preferred alternative or opt-out if given the chance to. This addresses research question 3.

All experimental designs were constructed using JMP software [16].

\section{Survey administration}

The experiment was platformed on the iSurvey toolkit available from the University of Southampton. Over 200 stakeholders were invited to participate through our existing professional networks and Macmillan Cancer Care and their digital team. We contacted all of the clinical commissioning groups in England as well as a number of cancer charities. In addition, though a smaller and overlapping pool of potential respondents, the professionals who participated in other stages of the study, had previously shown interest in the study, or had attended our launch event, were invited and encouraged to share the link with colleagues. The questionnaire was also 


\begin{tabular}{|c|c|c|c|c|}
\hline \multirow{11}{*}{$\begin{array}{l}\frac{\text { If vou }}{\text { want to }} \\
\underline{\text { remind }} \\
\text { yourself } \\
\underline{\text { of what }} \\
\underline{\text { each of }} \\
\frac{\text { the }}{\text { features }} \\
\frac{\text { means }}{\text { please }} \\
\underline{\text { click }} \\
\text { here }\end{array}$} & Feature & Dashboard A & Dashboard B & Dashboard C \\
\hline & Option to search & Yes: map and postcode & Yes: map and postcode & Yes: map and postcode \\
\hline & Graphs & Fixed graphs or pie charts & $\begin{array}{l}\text { User can choose and change } \\
\text { graphs }\end{array}$ & Fixed graphs or pie charts \\
\hline & Data quality & $\begin{array}{l}\text { Show graphs and pie charts } \\
\text { as well as comments even if } \\
\text { there is only one comment } \\
\text { for the chosen topic }\end{array}$ & $\begin{array}{l}\text { Show graphs and pie charts } \\
\text { as well as comments even if } \\
\text { there is only one comment } \\
\text { for the chosen topic }\end{array}$ & $\begin{array}{l}\text { Show graphs and pie charts } \\
\text { as well as comments even if } \\
\text { there is only one comment } \\
\text { for the chosen topic }\end{array}$ \\
\hline & Language & $\begin{array}{l}\text { Technical, with a dictionary } \\
\text { of terms }\end{array}$ & $\begin{array}{c}\text { Technical, with a dictionary } \\
\text { of terms }\end{array}$ & $\begin{array}{l}\text { Technical, with a dictionary } \\
\text { of terms }\end{array}$ \\
\hline & $\begin{array}{l}\text { Indicators } \\
\text { displayed }\end{array}$ & $\begin{array}{l}\text { User can choose up to } 6 \\
\text { out of } 12 \text { indicators of } \\
\text { patient experience }\end{array}$ & $\begin{array}{l}\text { User can choose up to } 6, \\
\text { out of } 12 \text { indicators of } \\
\text { patient experience }\end{array}$ & $\begin{array}{l}\text { User can choose up to } 6 \\
\text { out of } 12 \text { indicators of } \\
\text { patient experience }\end{array}$ \\
\hline & Filter & $\begin{array}{c}\text { Filter comments by gender AND } \\
\text { age AND ethnicity AND } \\
\text { condition/illness }\end{array}$ & $\begin{array}{c}\text { Filter comments by gender AND } \\
\text { age AND ethnicity AND } \\
\text { condition/illness }\end{array}$ & $\begin{array}{l}\text { Filter data by gender AND } \\
\text { age AND ethnicity AND } \\
\text { condition/illness }\end{array}$ \\
\hline & Staff role & Do not filter by staff role & Filter comments by staff role & Do not filter by staff role \\
\hline & $\begin{array}{l}\text { Upload your own } \\
\text { data }\end{array}$ & Yes & Yes & Yes \\
\hline & $\begin{array}{l}\text { Predictive } \\
\text { intelligence }\end{array}$ & No & Yes & No \\
\hline & Fee & $\$ 10$ & $\$ 20$ & $\$ 40$ \\
\hline
\end{tabular}

Please indicate which of the three Dashboards (A, B or C) you would choose if you had to subscribe to this online tool:

\begin{tabular}{llll}
\hline A & B & C \\
\hline & O & O \\
\hline
\end{tabular}

Suppose you were given the option to opt-out of subscribing to this service, what do you prefer?

$$
\begin{aligned}
& \text { I choose to keep the service indicated above } \\
& \text { I choose to opt-out of this online tool completely }
\end{aligned}
$$

Fig. 2 Example of choice set presented to individuals. Screenshot generated from iSurvey, the University of Southampton's survey generation and research tool

disseminated via members of our advisory group and steering committee, and shared within the Faculty of Health Sciences at the University of Southampton. The questionnaire was open for nine weeks, with one reminder. Ethics approval was obtained from an NHS National Research Ethics Committee (NRES 15/NS/0104) and the study was sponsored by the University of Southampton.

\section{DCE analysis}

Analysis of DCE data assumes random utility theory and a linear-in-parameters utility function. When independent and identically distributed extreme value type I distributed error terms are assumed McFadden's conditional logit (CL) arises [17]. This models the probability that an individual will choose a specific alternative from a set of three alternatives. Given that individual respondent characteristics do not change within a choice set, they cannot directly influence such probability. The coefficients (e.g. $\beta_{k}$ for attribute-level $k)$ estimated in such models denote the increase/decrease in utility obtained from an alternative possessing the characteristic $k$.

Relaxing some conditional logit assumptions, choices are further modelled through a nested logit (NL) model where alternatives are first grouped into nests (i.e. purchase or not-purchase) and the probability that an individual chooses an alternative from a set of available 
alternatives within a specific nest is modelled [18]. Again individual respondent characteristics cannot affect the choice of the alternative but can affect the choice of the nest (i.e. purchase or not-purchase).

\section{Willingness-to-pay values}

Following estimation of models and coefficients for each of the attribute levels, willingness-to-pay values can be calculated. As discussed previously, coefficients depict part-worth utility and as such present the relative importance of attribute levels. By taking ratios of coefficient one can calculate the marginal rates of substitution (MRS) between them, i.e. how much of an attribute level an individual is willing to lose to gain more of another attribute level. Incorporating a price component in the attributes allows one to translate such ratios into their monetary representations, i.e. WTP values. WTPs represent the amount of money an average individual is willing to pay to obtain a service/product that has a specific feature attribute level.

\section{Predicted probabilities}

Further inference on the results can be drawn from calculating predicted probabilities. These probabilities represent the likelihood that an individual will purchase a given product or not, or the change in the likelihood of purchasing a product or not when its features change. Specifically, we present three types of predicted probabilities.

a) The first one is used to provide better insight into the magnitude of the effect of each attribute level (i.e. how much it contributes to the attractiveness of the product). This may be termed dashboard desirability. For this we define a baseline product whose features are given in Table 3. Subsequently we create alternative dashboards that are identical to the baseline with the exception of only one attribute level. For instance, one alternative dashboard might be identical to the baseline except that it possesses the additional capability for the user to upload their own data into the dashboard (i.e. attribute: Upload own data - Yes). The possible configurations (i.e. the number of possible alternative products) are large so, without any loss of generality, we restrict ourselves to changing only one attribute level at a time, which results in a total of 12 alternative dashboards. The probability of purchase of each of these alternative dashboards is then calculated and compared to the baseline. This difference indicates the change in the predicted probability of purchase when one attribute level changes with respect to the baseline. Given that we have intentionally chosen the baseline dashboard to contain the least desired level of each feature, with the exception of price, where it is the cheapest, probability differences are expected to be positive, implying that the more desired features there are, the greater the probability of selecting the dashboard.

b) The second type of predicted probabilities follows a similar logic but gives an assessment of the importance of each attribute level in preventing an average individual from opting-out of purchasing the dashboard tool. In this case, we calculate the probability of opting-out for the baseline as well as all other alternative dashboards and we again compare them. More desirable features are expected to reduce the probability of opting-out. Given that in these calculations the presence of the opt-out as an option is necessary, this is only possible for the second stage of the DCE choice. Recall that we implement a two-stage elicitation strategy where individuals are first asked which of three alternative

Table $\mathbf{3}$ Characteristics of the baseline alternative in the DCE

\begin{tabular}{|c|c|}
\hline Attribute & Baseline value \\
\hline Search & No, Only regional data visible \\
\hline Graphs & Fixed graphs or pie charts \\
\hline Data resolution & $\begin{array}{l}\text { Show graphs and pie charts as well as comments even if there } \\
\text { is only } 1 \text { comment for the chosen topic }\end{array}$ \\
\hline Language & Technical, with a dictionary of terms \\
\hline Indicators displayed & Fixed indicators of patient experience shown at the same time \\
\hline Filter & Filter only by condition or illness (e.g. type of cancer) \\
\hline Staff role & Do not filter by staff role \\
\hline Upload own data & No \\
\hline Predictive intelligence & No predictive intelligence capability \\
\hline Annual subscription fee & $£ 250$ \\
\hline
\end{tabular}


dashboard they prefer and subsequently they are offered the option to keep their preferred alternative or opt-out altogether.

c) The third type calculates the unconditional predicted probability of purchase and of opt-out (i.e. declining purchase) for three hypothetical dashboards, i.e. the baseline, a fully-featured low price and a fully-featured high price alternative. Such figures give a sense of the overall tendency to purchase in the sample of respondents and can aid in building market scenarios that can guide market placement and revenue streams.

\section{Results}

Of the 152 individuals invited, 148 logged into the survey (i.e. a possible response rate of $97 \%$, though we are unable to determine a true response rate as we asked them to pass the link on). Of those, 116 responded to at least one choice set but did not finish the survey so that their data could not be used. In total, 32 respondents completed the DCE, giving a completion/retention rate of about $22 \%$. While identification of coefficients does not rest on sample size (i.e. the experimental design ensures that enough information is available to estimate parameters), the generalisability or robustness of the findings would need to be verified, given this retention rate.

\section{Descriptive statistics}

Before we look at the estimation results we discuss the make-up of the sample (Table 4). Overall, the mean age was 49 years with $81 \%$ females and $38 \%$ working for the NHS. Enquiring about information on individual circumstances related to NHS posts, band 7 was most common (accounting for 50\% of respondents), while management (58\% of respondents) was the most common professional area. Individuals with academic roles comprised 53\% of respondents; again this means findings need to be further verified with healthcare staff though most academics were also part-time clinicians or on local commissioning boards.

\section{Estimation results}

Table 5 presents the estimation result from three models. The conditional logit can be used to estimate the first stage of the DCE question (i.e. forced-choice without an opt-out) and the first and second stage of the DCE questions combined (i.e. three alternative dashboards plus an opt-out to choose from). Combinations of first and second stage are also analysed using a nested logit. Results for all three are given in Odds Ratios which indicate how likely one is to choose an alternative that features an attribute level compared to the baseline (research question 2).
Common patterns appear across models. Being able to 'Filter data' (by gender AND age AND ethnicity AND condition/illness) seems to be the most influential feature, followed by the ability to 'Search' (a hospital from a drop-down list). All three search features are highly desirable for respondents, while almost equally important is the ability to 'Upload one's own data'. Further, 'Filtering comments (by staff roles)' and 'Graphs customisation' also appear important, while 'Use of lay language' and 'Indicators display' only achieve limited significance. Interestingly, 'Data resolution' and 'Predictive intelligence' were not identified as important in any of the models even though identified as desirable in our scoping survey. Finally, cost of the dashboard was highly significant, suggesting that respondents were sensitive to price changes as predicted by economic theory. Overall, on average, individuals were very likely to decline to purchase the baseline service (i.e. almost 9 times more likely to decline purchase than to purchase), while females were much more likely to do so as indicated by the nested logit model (research question 3).

\section{WTP monetary valuations}

Table 6 presents WTP calculations (research question 1). Given that WTP are essentially non-linear combinations of the estimated coefficients, statistical significance and relative size closely follows the coefficient results. All three models point to an identical list of important attribute levels albeit there is some variation in the magnitude of the elicited WTP. This is largely explained by the different model assumptions and other model features, and in the vast majority, WTPs are not statistically different across the three models.

Overall, respondents are willing-to-pay $£ 1674$ to $£ 2447$ (conditional and nested logit) for their most preferred 'Search' feature (i.e. drop down list of hospitals), followed by 'Filter (by age, gender and condition)' which is valued at $£ 1644$ to $£ 2142$. The other two 'Search' options, by keyword and map/postcode, are valued at $£ 1364$ to $£ 2062$ and $£ 1357$ to $£ 1461$, respectively. 'Capability of uploading own data' was valued at $£ 1198$ to $£ 1377$ and finally, 'Filter by staff role' was valued at $£ 736$ to $£ 941$.

We should note that although the rest of the attribute levels do not appear as significant, this does not imply they are not desired in the dashboard. As discussed previously, coefficients convey a relative piece of information, namely how much more a feature is desired compared to the baseline or to the baseline level. As such, statistically insignificant WTP values imply that respondents did not systematically value dashboards with these attribute levels more than they valued dashboards with the respective bassline attribute level. For instance in the case of 'Graphs' (with two levels: a) 'Fixed graphs 
Table 4 Descriptive statistics of the collected sample $(n=32)$

\begin{tabular}{|c|c|c|c|}
\hline \multirow[t]{3}{*}{ Age } & Mean & Min & $\operatorname{Max}$ \\
\hline & 48.5 & 30.0 & \multirow[t]{2}{*}{77.0} \\
\hline & Frequency & Percentage & \\
\hline \multicolumn{4}{|l|}{ Sex } \\
\hline Male & 6.0 & 18.8 & \\
\hline Female & 26.0 & 81.3 & \\
\hline \multicolumn{4}{|l|}{ NHS staff } \\
\hline No & 20.0 & 62.5 & \\
\hline Yes & 12.0 & 37.5 & \\
\hline \multicolumn{4}{|l|}{ Band/grade } \\
\hline Band 7 & 6.0 & 50.0 & \\
\hline Band 8a & 2.0 & 16.7 & \\
\hline Band 8b & 1.0 & 8.3 & \\
\hline Band 8d & 2.0 & 16.7 & \\
\hline Other & 1.0 & 8.3 & \\
\hline \multicolumn{4}{|l|}{ Professional area } \\
\hline Clinical psychology & 1.0 & 8.3 & \\
\hline Management & 7.0 & 58.3 & \\
\hline Medicine/surgery & 1.0 & 8.3 & \\
\hline Nursing & 1.0 & 8.3 & \\
\hline Other & 1.0 & 8.3 & \\
\hline Physiotherapy/Occupational therapy & 1.0 & 8.3 & \\
\hline \multicolumn{4}{|l|}{ Area of specialty } \\
\hline Commissioning & 1.0 & 9.1 & \\
\hline Communications and Engagement & 1.0 & 9.1 & \\
\hline Complaints, Patient experience and Risk Manager & 1.0 & 9.1 & \\
\hline Diabetes and Obesity & 1.0 & 9.1 & \\
\hline Innovation evaluation and implementation & 1.0 & 9.1 & \\
\hline Musculoskeletal & 1.0 & 9.1 & \\
\hline Obstetrics and Gynaecology & 1.0 & 9.1 & \\
\hline Operational / Commissioning & 1.0 & 9.1 & \\
\hline Service Development Manager & 1.0 & 9.1 & \\
\hline Urology & 1.0 & 9.1 & \\
\hline Communications and patient experience & 1.0 & 9.1 & \\
\hline \multicolumn{4}{|l|}{ Role } \\
\hline Academic & 9.0 & 52.9 & \\
\hline Charity & 1.0 & 5.9 & \\
\hline Health Researcher & 1.0 & 5.9 & \\
\hline Healthwatch & 1.0 & 5.9 & \\
\hline Professional & 1.0 & 5.9 & \\
\hline Community engagement & 1.0 & 5.9 & \\
\hline Local authority officer & 1.0 & 5.9 & \\
\hline Manager of charity & 1.0 & 5.9 & \\
\hline Patient & 1.0 & 5.9 & \\
\hline
\end{tabular}


Table 5 Estimation results of the DCE. Data generated using JMP software Version 13.0

\begin{tabular}{|c|c|c|c|}
\hline & $\begin{array}{l}\text { Conditional Logit - } \\
\text { Forced choice }\end{array}$ & $\begin{array}{l}\text { Conditional Logit - } \\
\text { Opt-out }\end{array}$ & Nested Logit \\
\hline \multicolumn{4}{|l|}{ (a) Attribute estimates } \\
\hline $\begin{array}{l}\text { Search } \\
\text { Yes, choose a hospital from a drop down list }\end{array}$ & $\begin{array}{l}3.792^{* * *} \\
(1.796)\end{array}$ & $\begin{array}{l}2.763^{* * *} \\
(1.040)\end{array}$ & $\begin{array}{l}6.321^{* * *} \\
(4.241)\end{array}$ \\
\hline $\begin{array}{l}\text { Search } \\
\text { Yes, keyword search }\end{array}$ & $\begin{array}{l}2.962^{* *} \\
(1.386)\end{array}$ & $\begin{array}{l}2.539^{* * *} \\
(0.915)\end{array}$ & $\begin{array}{l}4.730^{* *} \\
(2.939)\end{array}$ \\
\hline $\begin{array}{l}\text { Search } \\
\text { Yes, map and postcode }\end{array}$ & $\begin{array}{l}2.948^{* *} \\
(1.423)\end{array}$ & $\begin{array}{l}2.318^{* * *} \\
(0.742)\end{array}$ & $\begin{array}{l}3.007 \\
(2.059)\end{array}$ \\
\hline $\begin{array}{l}\text { Graphs } \\
\text { User can choose and change graphs }\end{array}$ & $\begin{array}{l}1.627^{*} \\
(0.407)\end{array}$ & $\begin{array}{l}1.666^{* *} \\
(0.361)\end{array}$ & $\begin{array}{l}1.848^{* *} \\
(0.508)\end{array}$ \\
\hline $\begin{array}{l}\text { Data resolution } \\
\text { Show graphs and pie charts only if more than } 6 \text { responses, but show all comments }\end{array}$ & $\begin{array}{l}1.232 \\
(0.302)\end{array}$ & $\begin{array}{l}1.331 \\
(0.299)\end{array}$ & $\begin{array}{l}1.317 \\
(0.434)\end{array}$ \\
\hline $\begin{array}{l}\text { Language } \\
\text { Lay, that is no jargon }\end{array}$ & $\begin{array}{l}1.895^{* *} \\
(0.561)\end{array}$ & $\begin{array}{l}1.125 \\
(0.232)\end{array}$ & $\begin{array}{l}1.714 \\
(0.569)\end{array}$ \\
\hline $\begin{array}{l}\text { Indicators display } \\
\text { User can choose up to } 6 \text {, out of } 12 \text { indicators of patient experience }\end{array}$ & $\begin{array}{l}1.424^{*} \\
(0.305)\end{array}$ & $\begin{array}{l}1.221 \\
(0.226)\end{array}$ & $\begin{array}{l}1.576 \\
(0.437)\end{array}$ \\
\hline $\begin{array}{l}\text { Filter } \\
\text { Filter data by gender AND age AND ethnicity AND condition/illness }\end{array}$ & $\begin{array}{l}3.703^{* * *} \\
(0.907)\end{array}$ & $\begin{array}{l}3.193^{* * *} \\
(0.699)\end{array}$ & $\begin{array}{l}5.023^{* * *} \\
(1.647)\end{array}$ \\
\hline $\begin{array}{l}\text { Staff role } \\
\text { Filter comments by staff role }\end{array}$ & $\begin{array}{l}1.798^{* *} \\
(0.454)\end{array}$ & $\begin{array}{l}1.568^{* * *} \\
(0.247)\end{array}$ & $\begin{array}{l}2.033^{* *} \\
(0.618)\end{array}$ \\
\hline $\begin{array}{l}\text { Upload own data } \\
\text { Yes }\end{array}$ & $\begin{array}{l}2.596^{* * *} \\
(0.723)\end{array}$ & $\begin{array}{l}1.742^{* * *} \\
(0.355)\end{array}$ & $\begin{array}{l}2.823^{* * *} \\
(1.119)\end{array}$ \\
\hline $\begin{array}{l}\text { Predictive intelligence } \\
\text { Predictive intelligence capability to inform and help plan capacity }\end{array}$ & $\begin{array}{l}1.144 \\
(0.261)\end{array}$ & $\begin{array}{l}1.144 \\
(0.275)\end{array}$ & $\begin{array}{l}1.144 \\
(0.356)\end{array}$ \\
\hline Fee & $\begin{array}{l}0.999^{* * *} \\
(0.0002)\end{array}$ & $\begin{array}{l}0.999^{* * *} \\
(0.0002)\end{array}$ & $\begin{array}{l}0.999^{* * *} \\
(0.0002)\end{array}$ \\
\hline Decline the service (Opt-out) & & $\begin{array}{l}8.823^{* * *} \\
(4.574)\end{array}$ & \\
\hline \multicolumn{4}{|l|}{ (b) Probability to decline the service } \\
\hline Age & & & $\begin{array}{l}0.994 \\
(0.029)\end{array}$ \\
\hline Sex (1 if female) & & & $\begin{array}{l}29.35^{* * *} \\
(29.29)\end{array}$ \\
\hline NHS staff & & & $\begin{array}{l}1.322 \\
(0.891)\end{array}$ \\
\hline Constant & & & $\begin{array}{l}0.0506 \\
(0.092)\end{array}$ \\
\hline \# of respondents & 33 & & \\
\hline
\end{tabular}

Robust standard errors in parentheses; ${ }^{* *} p<0.01,{ }^{* *} p<0.05,{ }^{*} p<0.1$

or pie charts' and b) 'User can choose and change graphs') an insignificant WTP suggests respondents were not willing to pay more for a dashboard with the user specified graphs compared to a dashboard with fixed graphs. This is vastly different from the notion that graphics are altogether not important to the dashboard users.

\section{Predicted probabilities calculations}

The results from the predicted probabilities calculations are given in Table 7. Recall that the values in the table are changes in predicted probabilities and as such interpreted as a percentage point change. Positive values imply an increase in the chances of purchasing an alternative dashboard level (i.e. identical to the baseline dashboard in all aspects apart from the specific attribute indicated) compared to the baseline dashboard. Correspondingly, negative values suggest the attribute level evaluated is less desired than the respective baseline attribute level and as such the chances of purchasing the alternative dashboard are lower than those of the baseline dashboard (research question 3).

All three models point to similar ranking across attribute levels, with the 'Search' feature of drop-down hospital list increasing the chances of an alternative being selected by 32 percentage points (p.p.) in the forced- 
Table 6 Willingness-to-pay values from the DCE estimations. Data generated using JMP software Version 13.0

\begin{tabular}{|c|c|c|c|}
\hline & $\begin{array}{l}\text { Conditional Logit - } \\
\text { Forced choice }\end{array}$ & $\begin{array}{l}\text { Conditional Logit - } \\
\text { Opt-out }\end{array}$ & Nested Logit \\
\hline $\begin{array}{l}\text { Search } \\
\text { Yes, choose a hospital from a drop down list }\end{array}$ & $\begin{array}{l}1673.75 \\
(2.19)^{* *}\end{array}$ & $\begin{array}{l}1836.33 \\
(2.34)^{* *}\end{array}$ & $\begin{array}{l}2446.80 \\
(2.37)^{* *}\end{array}$ \\
\hline $\begin{array}{l}\text { Search } \\
\text { Yes, keyword search }\end{array}$ & $\begin{array}{l}1363.52 \\
(2.06)^{* *}\end{array}$ & $\begin{array}{l}1683.55 \\
(2.33)^{* *}\end{array}$ & $\begin{array}{l}2062.10 \\
(2.42)^{* *}\end{array}$ \\
\hline $\begin{array}{l}\text { Search } \\
\text { Yes, map and postcode }\end{array}$ & $\begin{array}{l}1357.49 \\
(2.01)^{* *}\end{array}$ & $\begin{array}{l}1518.86 \\
(2.41)^{* *}\end{array}$ & $\begin{array}{l}1460.96 \\
(1.67)^{*}\end{array}$ \\
\hline $\begin{array}{l}\text { Graphs } \\
\text { User can choose and change graphs }\end{array}$ & $\begin{array}{l}611.41 \\
(1.57)\end{array}$ & $\begin{array}{l}922.53 \\
(1.57)\end{array}$ & $\begin{array}{l}815.25 \\
(1.61)\end{array}$ \\
\hline $\begin{array}{l}\text { Data resolution } \\
\text { Show graphs and pie charts only if more than } 6 \text { responses, but show all comments }\end{array}$ & $\begin{array}{l}261.75 \\
(0.78)\end{array}$ & $\begin{array}{l}516.10 \\
(1.11)\end{array}$ & $\begin{array}{l}365.61 \\
(0.77)\end{array}$ \\
\hline $\begin{array}{l}\text { Language } \\
\text { Lay, that is no jargon }\end{array}$ & $\begin{array}{l}802.76 \\
(1.89)\end{array}$ & $\begin{array}{l}212.45 \\
(0.61)\end{array}$ & $\begin{array}{l}715.41 \\
(1.56)\end{array}$ \\
\hline $\begin{array}{l}\text { Indicators display } \\
\text { User can choose up to } 6 \text {, out of } 12 \text { indicators of patient experience }\end{array}$ & $\begin{array}{l}443.44 \\
(1.63)\end{array}$ & $\begin{array}{l}360.70 \\
(1.24)\end{array}$ & $\begin{array}{l}603.35 \\
(1.76)^{*}\end{array}$ \\
\hline $\begin{array}{l}\text { Filter } \\
\text { Filter data by gender AND age AND ethnicity AND condition/illness }\end{array}$ & $\begin{array}{l}1643.74 \\
(2.85)^{* * *}\end{array}$ & $\begin{array}{l}2097.37 \\
(2.65)^{* * *}\end{array}$ & $\begin{array}{l}2141.81 \\
(2.55)^{* *}\end{array}$ \\
\hline $\begin{array}{l}\text { Staff role } \\
\text { Filter comments by staff role }\end{array}$ & $\begin{array}{l}736.55 \\
(2.13)^{* *}\end{array}$ & $\begin{array}{l}812.63 \\
(2.06)^{* *}\end{array}$ & $\begin{array}{l}941.73 \\
(2.03)^{* *}\end{array}$ \\
\hline $\begin{array}{l}\text { Upload own data } \\
\text { Yes }\end{array}$ & $\begin{array}{l}1197.61 \\
(2.29)^{* *}\end{array}$ & $\begin{array}{l}1002.80 \\
(2.01)^{* *}\end{array}$ & $\begin{array}{l}1376.96 \\
(2.04)^{* *}\end{array}$ \\
\hline $\begin{array}{l}\text { Predictive intelligence } \\
\text { Predictive intelligence capability to inform and help plan capacity }\end{array}$ & $\begin{array}{l}168.78 \\
(0.54)\end{array}$ & $\begin{array}{l}243.31 \\
(0.51)\end{array}$ & $\begin{array}{l}178.27 \\
(0.40)\end{array}$ \\
\hline
\end{tabular}

$z$-statistics in parentheses; ${ }^{* * *} p<0.01,{ }^{* *} p<0.05,{ }^{*} p<0.1$

choice and 28 p.p. in the NL. Equally large changes in likelihood are obtained by the 'Filter (by age, gender and condition)' feature, increasing chances by 32 p.p. and 25 p.p., respectively. The remaining 'Search' levels and 'Upload own data' capabilities follow. Looking at the price effect, an increase of the annual fee from $£ 250$ to $£ 1500$ drops the probability of purchase by about 18 p.p. in the forced choice and 10 p.p. in the NL.

Moving on to the second type of predicted probabilities where we calculate the change in the predicted probability of opting-out, negative values imply an attribute level will result in a lower probability to opt-out (i.e. they are a desired feature), whereas positive values suggest an increased chance of opting-out and not purchasing (i.e. an unattractive feature). For both the CL and NL models we see that the changes in the opt-out probabilities are relatively small, with about 13 p.p. and 3.5 p.p. drop in the CL and NL, respectively for 'Filtering (by age, gender and condition)'. 'Search' features follow, with values between 7 p.p. and 9 p.p. for the $C L$ and 4.2 p.p. and 2 p.p. for the NL, suggesting that all features are desirable and reduce the chances of opt-out (research questions 1,2 and 3).

We note that such drops in the opt-out probability potentially appear small. However, this is to be expected given that there is a large tendency of respondents to opt-out of purchasing the baseline dashboard, which in essence is the least desirable dashboard that can be configured given the attributes specified. To gain insight into the overall attractiveness of the dashboard tool and the potential market demand, the third type of predicted probabilities is presented in Table 8 . Individuals in the vast majority of cases (i.e. 91\%) decline purchase of the baseline dashboard but will choose to purchase when a fully featured alternative is offered with $89 \%$ for the low and $80.5 \%$ for the high pricing options. From this we can also see the effect of price on a highly desirable dashboard, where an increase of $£ 1250$ (i.e. from $£ 250$ to $£ 1500)$ reduces the probability of purchase by about 8.5 percentage points (research question 3).

Basic cost-benefit evaluation of the dashboard online tool We performed a basic cost-benefit simulation exercise to evaluate the profitability of a dashboard tool venture, using the three dashboards from Table 8, i.e. the baseline, a fully-featured low price and a fully-featured high price alternative. We assumed the dashboard is offered to 100,500 and 1000 potential interested clients (a range chosen to highlight the possible profitability of the dashboard in a hypothetical market). The product up-take was calculated from Table 8 to determine purchasing behaviour (research question 3). For the calculation of costs, we only took into account the initial development cost (i.e. the value of the overall grant of $£ 412,242$, which encompassed various small studies culminating in development of the toolkit) and assumed a varying 
Table 7 Predicted probabilities calculations from DCE estimations. Data generated using JMP software Version 13.0

\begin{tabular}{|c|c|c|c|c|c|}
\hline & \multirow{2}{*}{$\begin{array}{l}\text { Conditional Logit - } \\
\text { Forced choice } \\
\text { Difference in } \\
\text { predicted probability } \\
\text { from Baseline }\end{array}$} & \multicolumn{2}{|l|}{$\begin{array}{l}\text { Conditional Logit - } \\
\text { Opt-out }\end{array}$} & \multicolumn{2}{|l|}{ Nested Logit } \\
\hline & & $\begin{array}{l}\text { Difference in } \\
\text { predicted probability } \\
\text { from Baseline }\end{array}$ & $\begin{array}{l}\text { Change in } \\
\text { predicted } \\
\text { probability of opt- } \\
\text { out }\end{array}$ & $\begin{array}{l}\text { Difference in } \\
\text { predicted probability } \\
\text { from Baseline }\end{array}$ & $\begin{array}{l}\text { Change in } \\
\text { predicted } \\
\text { probability of opt- } \\
\text { out }\end{array}$ \\
\hline $\begin{array}{l}\text { Search } \\
\text { Yes, choose a hospital from a drop } \\
\text { down list }\end{array}$ & 32.2 & 10.9 & -9.1 & 27.9 & -4.2 \\
\hline $\begin{array}{l}\text { Search } \\
\text { Yes, keyword search }\end{array}$ & 26.4 & 9.7 & -8.1 & 23.8 & -3.4 \\
\hline $\begin{array}{l}\text { Search } \\
\text { Yes, map and postcode }\end{array}$ & 26.3 & 8.4 & -7.0 & 16.8 & -2.1 \\
\hline $\begin{array}{l}\text { Graphs } \\
\text { User can choose and change graphs }\end{array}$ & 11.6 & 4.5 & -3.7 & 9.0 & -1.0 \\
\hline $\begin{array}{l}\text { Data resolution } \\
\text { Show graphs and pie charts only if } \\
\text { more than } 6 \text { responses, but show all } \\
\text { comments }\end{array}$ & 4.8 & 2.3 & -1.9 & 3.9 & -0.4 \\
\hline $\begin{array}{l}\text { Language } \\
\text { Lay, that is no jargon }\end{array}$ & 15.4 & 0.9 & -0.7 & 7.8 & -0.9 \\
\hline $\begin{array}{l}\text { Indicators display } \\
\text { User can choose up to } 6 \text {, out of } 12 \\
\text { indicators of patient experience }\end{array}$ & 8.3 & 1.5 & -1.3 & 6.5 & -0.7 \\
\hline $\begin{array}{l}\text { Filter } \\
\text { Filter data by gender AND age AND } \\
\text { ethnicity AND condition/illness }\end{array}$ & 31.6 & 13.2 & -11.0 & 24.7 & -3.5 \\
\hline $\begin{array}{l}\text { Staff role } \\
\text { Filter comments by staff role }\end{array}$ & 14.0 & 3.8 & -3.2 & 10.5 & -1.2 \\
\hline $\begin{array}{l}\text { Upload own data } \\
\text { Yes }\end{array}$ & 23.2 & 4.9 & -4.1 & 15.8 & -2.0 \\
\hline $\begin{array}{l}\text { Predictive intelligence } \\
\text { Predictive intelligence capability to } \\
\text { inform and help plan capacity }\end{array}$ & 3.1 & 1.0 & -0.8 & 1.8 & -0.2 \\
\hline $\begin{array}{l}\text { Fee } \\
£ 1500\end{array}$ & -17.7 & -3.6 & 3.1 & -10.0 & 1.0 \\
\hline
\end{tabular}

The Baseline is an alternative that has the following features:

Search - No, Only regional data visible

Graphs - Fixed graphs or pie charts

Data resolution - Show graphs and pie charts as well as comments even if there is only 1 comment for the chosen topic

Language - Technical, with a dictionary of terms

Indicators displayed - Fixed indicators of patient experience shown at the same time

Filter - Filter only by condition or illness (e.g. type of cancer)

Staff role - Do not filter by staff role

Upload own data - No

Predictive intelligence - No predictive intelligence capability

Fee $-£ 250$

annual maintenance cost depending on the number of clients (i.e. $£ 50 \mathrm{~K}$ for 100 potential clients, $£ 100 \mathrm{~K}$ for 500 potential clients, $£ 150 \mathrm{~K}$ for 1000 potential clients). Finally, we assumed a product life of 5 years and an interest rate of $3 \%$.

From Table 9 it is apparent that the baseline dashboard is not a viable option for any of these numbers of potential clients, largely due to its very low chances of uptake (i.e. even for 1000 potential clients, only 90 purchases are predicted). Moving on to the full-featured option with the low pricing strategy, the product becomes profitable over a 5 year period only for 1000 potential clients (i.e. 890 purchases per year). Finally, for the fullfeatured option in the high pricing strategy the product becomes highly profitable for 500 potential clients (i.e. 403 purchases per year) and more so for 1000 potential clients (i.e. 805 purchases per year).

\section{Synthesising the DCE results with those from previous and subsequent stages of the PRESENT project}

In the final part of the PRESENT study we wished to consider how people actually used our working 
Table 8 Predicted probabilities of purchase and opt-out for three representative dashboards. Data generated using JMP software Version 13.0

\begin{tabular}{|c|c|c|c|}
\hline & Baseline Dashboard & Fully-featured Low price & Fully-featured High price \\
\hline & $\begin{array}{l}\text { Search } \\
\text { No, Only regional data visible }\end{array}$ & $\begin{array}{l}\text { Search } \\
\text { Yes, choose a hospital from a drop } \\
\text { down list }\end{array}$ & $\begin{array}{l}\text { Search } \\
\text { Yes, choose a hospital from a drop } \\
\text { down list }\end{array}$ \\
\hline & Fixed graphs or pie charts & User can choose and change graphs & User can choose and change graphs \\
\hline & $\begin{array}{l}\text { Data resolution } \\
\text { Show graphs and pie charts as well as } \\
\text { comments even if there is only } 1 \text { comment for } \\
\text { the chosen topic }\end{array}$ & $\begin{array}{l}\text { Data resolution } \\
\text { Show graphs and pie charts only if } \\
\text { more than } 6 \text { responses, but show all } \\
\text { comments }\end{array}$ & $\begin{array}{l}\text { Data resolution } \\
\text { Show graphs and pie charts only if } \\
\text { more than } 6 \text { responses, but show all } \\
\text { comments }\end{array}$ \\
\hline & $\begin{array}{l}\text { Language } \\
\text { Technical, with a dictionary of terms }\end{array}$ & $\begin{array}{l}\text { Language } \\
\text { Lay, that is no jargon }\end{array}$ & $\begin{array}{l}\text { Language } \\
\text { Lay, that is no jargon }\end{array}$ \\
\hline & $\begin{array}{l}\text { Indicators displayed } \\
\text { Fixed indicators of patient experience shown at } \\
\text { the same time }\end{array}$ & $\begin{array}{l}\text { Indicators display } \\
\text { User can choose up to 6, out of } 12 \\
\text { indicators of patient experience }\end{array}$ & $\begin{array}{l}\text { Indicators display } \\
\text { User can choose up to } 6 \text {, out of } 12 \\
\text { indicators of patient experience }\end{array}$ \\
\hline & $\begin{array}{l}\text { Filter } \\
\text { Filter only by condition or illness (e.g. type of } \\
\text { cancer) }\end{array}$ & $\begin{array}{l}\text { Filter } \\
\text { Filter data by gender AND age AND } \\
\text { ethnicity AND condition/illness }\end{array}$ & $\begin{array}{l}\text { Filter } \\
\text { Filter data by gender AND age AND } \\
\text { ethnicity AND condition/illness }\end{array}$ \\
\hline & $\begin{array}{l}\text { Staff role } \\
\text { Do not filter by staff role }\end{array}$ & $\begin{array}{l}\text { Staff role } \\
\text { Filter comments by staff role }\end{array}$ & $\begin{array}{l}\text { Staff role } \\
\text { Filter comments by staff role }\end{array}$ \\
\hline & $\begin{array}{l}\text { Upload own data } \\
\text { No }\end{array}$ & $\begin{array}{l}\text { Upload own data } \\
\text { Yes }\end{array}$ & $\begin{array}{l}\text { Upload own data } \\
\text { Yes }\end{array}$ \\
\hline & $\begin{array}{l}\text { Predictive intelligence } \\
\text { No predictive intelligence capability }\end{array}$ & $\begin{array}{l}\text { Predictive intelligence } \\
\text { Predictive intelligence capability to } \\
\text { inform and help plan capacity }\end{array}$ & $\begin{array}{l}\text { Predictive intelligence } \\
\text { Predictive intelligence capability to } \\
\text { inform and help plan capacity }\end{array}$ \\
\hline & $\begin{array}{l}\text { Fee } \\
£ 250\end{array}$ & $\begin{array}{l}\text { Fee } \\
£ 250\end{array}$ & $\begin{array}{l}\text { Fee } \\
£ 1500\end{array}$ \\
\hline $\begin{array}{l}\text { Prob. of } \\
\text { purchase }\end{array}$ & $9 \%$ & $89 \%$ & $80.5 \%$ \\
\hline $\begin{array}{l}\text { Prob. to } \\
\text { decline } \\
\text { purchase }\end{array}$ & $91 \%$ & $11 \%$ & $19.5 \%$ \\
\hline
\end{tabular}

prototype, refined following our DCE. We observed 13 NHS managers at their workplaces in three diverse parts of England as they 'walked through' the dashboard to answer a relevant hypothetical question about cancer care. Each walkthrough and an associated interview lasted on average $2 \mathrm{~h}$ and was videoed. Walkthroughs were structured according to published guidance [15, 19] and designed to elicit information on our system's heuristics, usefulness in finding the answer to the hypothetical question (each participant devised their own question), and implementation barriers and enablers. This approach, which was different to the unstructured cognitive interviews used in our questionnaire development, meant we evaluated the quality of the user interface and system behaviour, not the actions of participants.

At the end of this stage we used a triangulation matrix to compare findings across the different parts of the study as a synthesis of study findings on dashboard attributes. Methods were the columns and attributes the rows. We used this matrix to examine convergences and divergences, which included a return to the raw data, to gain a deeper understanding of the requirements of our potential end users and the different types of data afforded by the different methods used.

Searches and filters were important across our data but the suggested form they should take differed according to the approach we used to explore them, as did the colours to use in the charts (red-amber-green or a more neutral scheme) and the use of maps to indicate patterns in the data. Our final synthesis summary can be seen in Table 10.

\section{Discussion}

In this paper we have presented the development of an online questionnaire DCE to elicit individual preferences for features for an online dashboard, and explored results. The choice of an online questionnaire for our experiment was appropriate given that a technology was being assessed. We were not interested in the exact content of the dashboard, which had been determined from previous stages of the study [1], but on the availability of features and customisation options and how they affect individuals' purchasing behaviours. In other words, the 
Table 9 Basic cost-benefit evaluation of a dashboard tool. Data generated using JMP software Version 13.0

\begin{tabular}{|c|c|c|c|}
\hline Revenues & Baseline & $\begin{array}{l}\text { Fully-featured low } \\
\text { price }\end{array}$ & $\begin{array}{l}\text { Fully-featured high } \\
\text { price }\end{array}$ \\
\hline Probability of purchase (out of potential clients) & $9.0 \%$ & $89.0 \%$ & $80.5 \%$ \\
\hline Product price & $£ 250$ & $£ 250$ & $£ 1500$ \\
\hline \multicolumn{4}{|l|}{ Annual revenue } \\
\hline for 100 potential clients & $£ 2250$ & $£ 22,250$ & $£ 120,750$ \\
\hline for 500 potential clients & $£ 11,250$ & $£ 111,250$ & $£ 603,750$ \\
\hline for 1000 potential clients & $£ 22,500$ & $£ 222,500$ & $£ 1,207,500$ \\
\hline \multicolumn{4}{|c|}{ Present value of total revenue (over a period of 5 years with an interest rate of 3\%) } \\
\hline for 100 potential clients & $£ 10,304$ & $£ 101,898$ & $£ 553,000$ \\
\hline for 500 potential clients & $£ 51,522$ & $£ 509,492$ & $£ 2,764,998$ \\
\hline for 1000 potential clients & $£ 103,043$ & $£ 1,018,985$ & $£ 5,529,996$ \\
\hline
\end{tabular}

\section{Costs}

Development Cost

Annual maintenance cost

Present value of total costs (over a period of 5 years with an interest rate of $3 \%$ )

Notes

- A product life of 5 years is assumed

- Interest rate of $3 \%$

purchasing behaviour elicited in this context assumes that individuals are already aware of the importance of the information offered by the online dashboard and as such we assess how the various features of such a dashboard influence the probability of purchasing the product. In this way we can determine which features are the most important and triangulate these with the results from other forms of assessment. At the same time, we allowed individuals to opt-out of purchasing, which affords the opportunity to elicit a demand function for the product. Individuals could opt-out because they disliked one or more features of the product.

The DCE is a useful tool in the development and evaluation of this type of intervention as it renders feasible an assessment of the intervention's dimensions prior to its release in the market. Findings suggest that certain features are highly desirable, namely the search function, filtering, and upload own data being the top choices. Further, a range of WTP values is observed, mostly towards the upper end of the distribution that was specified in the price attribute, again suggesting that certain features were highly valued and would contribute significant added value in a potential dashboard. Finally, in terms of the market demand for three representative dashboards we found purchasing behaviour to be very much dependent on the dashboard features, going from a 10 to $90 \%$ probability to purchase when we moved from a baseline dashboard to a fully-featured one.
In the preliminary and developmental parts of the study (stages 1 and 2) we effectively asked stakeholders for their considered impressions of what they believe they are doing in preattentive processing (i.e. subconscious cognitive processes) and we explored this in our scoping review. It could be argued that our DCE work attempted to get at preattentive processing more objectively. Therefore the information obtained from this DCE was particularly helpful for refining the prototype dashboard developed for the PRESENT study. Since all features were desired to at least some degree, and we could not list them in order of importance from other stages of the study, the DCE was critical in determining which features were least desired. This meant we were able to make decisions on which features to prioritise in further development. This was especially useful when programming constraints meant we could not have particular combinations of features in our final prototype or when there was lack of clarity from our other data. The DCE also gave the team confidence in the desirability of the dashboard. Results were also used, with data from other parts of the study, to develop a checklist of desirable healthcare dashboard features. The holistic approach that we used in PRESENT to co-create our dashboard, incorporating human, organisational, economic and technology dimensions, is increasingly recognised as necessary. This is shown for example by the development of holistic, evidence based frameworks such as that of the Centre for eHealth Research and Disease 
Table 10 Summary of our final synthesis of the different sources of data in the PRESENT study, including the DCE

\begin{tabular}{|c|c|c|c|c|c|c|}
\hline \multirow{2}{*}{$\begin{array}{l}\text { Design } \\
\text { features }\end{array}$} & \multirow[t]{2}{*}{ Subsets } & \multicolumn{4}{|l|}{ Source of data } & \multirow{2}{*}{$\begin{array}{l}\text { Consensus } \\
\text { across data } \\
\text { sources }\end{array}$} \\
\hline & & Systematic review & $\begin{array}{l}\text { Concept mapping } \\
(\text { Pts }=29, \mathrm{HCPs}=6)\end{array}$ & $\begin{array}{l}\text { Walkthrough } \\
(\mathrm{HCPs}=13)\end{array}$ & $\begin{array}{l}\text { DCE ( } n=32 \text {, mixed) NB } \\
\text { DCE ranked features } \\
\text { rather than determining } \\
\text { them }\end{array}$ & \\
\hline \multirow[t]{2}{*}{ Uses } & Patients & \multirow[t]{2}{*}{$\begin{array}{l}\text { Simple to follow, clear layout which } \\
\text { anticipates user's workflow and } \\
\text { needs (goal directed); time-saving }\end{array}$} & $\begin{array}{l}\text { Support, planning, } \\
\text { comparisons, } \\
\text { choice }\end{array}$ & \multirow{2}{*}{$\begin{array}{l}\text { Identify areas of } \\
\text { need } \\
\text { Plan } \\
\text { improvements } \\
\text { Seek funding } \\
\text { Show successes } \\
\text { Time-saving }\end{array}$} & \multirow[t]{2}{*}{$\begin{array}{l}\text { Option to tailor themes } \\
\text { of relatively low priority }\end{array}$} & \multirow[t]{2}{*}{$\begin{array}{l}\text { Broad } \\
\text { agreement } \\
\text { across sources }\end{array}$} \\
\hline & HCPs & & $\begin{array}{l}\text { Identify areas of } \\
\text { need } \\
\text { Plan improvements }\end{array}$ & & & \\
\hline Timely data & & N/A & Important & Important & $\mathrm{n} / \mathrm{a}$ & $\begin{array}{l}\text { Agreement } \\
\text { from two } \\
\text { sources }\end{array}$ \\
\hline \multirow[t]{3}{*}{ Functions } & Navigation & $\begin{array}{l}\text { Clear and simple } \\
\text { Labelling of buttons } \\
\text { Shortcuts } \\
\text { Avoid scrolling }\end{array}$ & $\begin{array}{l}\text { Simple } \\
\text { Scrolling OK }\end{array}$ & $\begin{array}{l}\text { Clear and simple } \\
\text { Help prompts / } \\
\text { pop-up illustra- } \\
\text { tions on use } \\
\text { Shortcuts } \\
\text { Scrolling OK }\end{array}$ & $\mathrm{n} / \mathrm{a}$ & $\begin{array}{l}\text { Some } \\
\text { agreement, } \\
\text { some } \\
\text { disagreement }\end{array}$ \\
\hline & $\begin{array}{l}\text { Search and } \\
\text { Filtering }\end{array}$ & $\begin{array}{l}\text { Ability to personalise and tailor } \\
\text { depending on needs and } \\
\text { preferences } \\
\text { Multiple comparisons }\end{array}$ & $\begin{array}{l}\text { Keyword search } \\
\text { Highly } \\
\text { customisable } \\
\text { filtering } \\
\text { Compare hospitals } \\
\text { /staff } \\
\text { Dislike dropdown } \\
\text { lists }\end{array}$ & $\begin{array}{l}\text { Keyword search } \\
\text { Multiple filtering } \\
\text { options (e.g. } \\
\text { demographic) } \\
\text { Need to see } \\
\text { non-responders } \\
\text { Compare } \\
\text { hospitals } \\
\text { and wards }\end{array}$ & $\begin{array}{l}\text { Dropdown menus } \\
\text { slightly preferred over } \\
\text { keyword search, both } \\
\text { important } \\
\text { Multiple filtering options } \\
\text { important }\end{array}$ & $\begin{array}{l}\text { Some } \\
\text { agreement, } \\
\text { some } \\
\text { disagreement }\end{array}$ \\
\hline & Export & $\begin{array}{l}\text { The option to print/download is } \\
\text { valued and desirable to both Pts } \\
\text { and HCPs }\end{array}$ & Print options & $\begin{array}{l}\text { Need export / } \\
\text { report function }\end{array}$ & $\mathrm{n} / \mathrm{a}$ & $\begin{array}{l}\text { Agreement } \\
\text { from three } \\
\text { sources }\end{array}$ \\
\hline \multirow[t]{5}{*}{ Presentation } & Colours & $\begin{array}{l}\text { RAG liked (bright, distinct and } \\
\text { highly contrasting colours) }\end{array}$ & $\begin{array}{l}\text { RAG colours } \\
\text { disliked }\end{array}$ & RAG liked & $\mathrm{n} / \mathrm{a}$ & $\begin{array}{l}\text { Disagreement } \\
\text { between } \\
\text { sources }\end{array}$ \\
\hline & Drill-down & Important & Important & Important & $\mathrm{n} / \mathrm{a}$ & $\begin{array}{l}\text { Agreement } \\
\text { from three } \\
\text { sources }\end{array}$ \\
\hline & Maps & $\mathrm{n} / \mathrm{a}$ & Not liked & $\mathrm{n} / \mathrm{a}$ & Maps relatively preferred & $\begin{array}{l}\text { Disagreement } \\
\text { between } \\
\text { sources }\end{array}$ \\
\hline & $\begin{array}{l}\text { Infographics } \\
\text { and data }\end{array}$ & $\begin{array}{l}\text { Line and bar charts clear and } \\
\text { appropriate for providers } \\
\text { 'at a glance' overviews }\end{array}$ & $\begin{array}{l}\text { Pie and bar charts } \\
\% \text { and raw } \\
\text { numbers } \\
\text { Summary overview } \\
\text { of themes }\end{array}$ & $\begin{array}{l}\text { Pie or bar chart } \\
\% \text {, raw numbers } \\
\text { and } \\
\text { denominators } \\
\text { Summary } \\
\text { overview }\end{array}$ & $\begin{array}{l}\mathrm{n} / \mathrm{a} \text { (function to change } \\
\text { chart type relatively } \\
\text { unimportant) }\end{array}$ & $\begin{array}{l}\text { Broad } \\
\text { agreement } \\
\text { across sources }\end{array}$ \\
\hline & $\begin{array}{l}\text { Language } \\
\text { and feel }\end{array}$ & $\begin{array}{l}\text { Simple language without } \\
\text { abbreviations and jargon } \\
\text { Images informative, not solely } \\
\text { decorative }\end{array}$ & $\mathrm{n} / \mathrm{a}$ & $\begin{array}{l}\text { Match to user } \\
\text { group - photos, } \\
\text { words } \\
\text { Minimal but } \\
\text { informative text } \\
\text { Help/prompts } \\
\text { needed on } \\
\text { dashboard (low } \\
\text { priority) }\end{array}$ & Relatively low priority & $\begin{array}{l}\text { Broad } \\
\text { agreement } \\
\text { across sources }\end{array}$ \\
\hline \multirow[t]{2}{*}{$\begin{array}{l}\text { Data } \\
\text { integrity }\end{array}$} & $\begin{array}{l}\text { Data validity } \\
\text { \& labels }\end{array}$ & Elements all well explained & $n / a$ & $\begin{array}{l}\text { Validity shown } \\
\text { Elements all well } \\
\text { explained }\end{array}$ & $\mathrm{n} / \mathrm{a}$ & $\begin{array}{l}\text { Agreement } \\
\text { from two } \\
\text { sources }\end{array}$ \\
\hline & $\begin{array}{l}\text { Security } \\
\text { Access }\end{array}$ & $\begin{array}{l}\text { Easy access \& simple URL } \\
\text { Stand-alone systems/ separate } \\
\text { login less likely to be used }\end{array}$ & $\begin{array}{l}\text { Registration can } \\
\text { put people off } \\
\text { accessing }\end{array}$ & $\begin{array}{l}\text { Open to all. } \\
\text { Passwords will } \\
\text { deter }\end{array}$ & $\mathrm{n} / \mathrm{a}$ & $\begin{array}{l}\text { Agreement } \\
\text { from three } \\
\text { sources }\end{array}$ \\
\hline
\end{tabular}


Table 10 Summary of our final synthesis of the different sources of data in the PRESENT study, including the DCE (Continued)

\begin{tabular}{|c|c|c|c|c|c|c|}
\hline \multirow{2}{*}{$\begin{array}{l}\text { Design } \\
\text { features }\end{array}$} & \multirow[t]{2}{*}{ Subsets } & \multicolumn{4}{|l|}{ Source of data } & \multirow{2}{*}{$\begin{array}{l}\text { Consensus } \\
\text { across data } \\
\text { sources }\end{array}$} \\
\hline & & Systematic review & $\begin{array}{l}\text { Concept mapping } \\
(\text { Pts }=29, \mathrm{HCPs}=6)\end{array}$ & $\begin{array}{l}\text { Walkthrough } \\
(\mathrm{HCPS}=13)\end{array}$ & $\begin{array}{l}\text { DCE }(n=32, \text { mixed) NB } \\
\text { DCE ranked features } \\
\text { rather than determining } \\
\text { them }\end{array}$ & \\
\hline & & But security must be prioritised & & & & \\
\hline \multirow[t]{3}{*}{ Other } & $\begin{array}{l}\text { Community } \\
\text { function }\end{array}$ & $\begin{array}{l}\text { Forum, chat room and similar } \\
\text { community features }\end{array}$ & $\begin{array}{l}\text { Forum, chat room } \\
\text { and similar } \\
\text { community } \\
\text { features }\end{array}$ & $\mathrm{n} / \mathrm{a}$ & $\mathrm{n} / \mathrm{a}$ & $\begin{array}{l}\text { Agreement } \\
\text { from two } \\
\text { sources }\end{array}$ \\
\hline & $\begin{array}{l}\text { Other } \\
\text { information }\end{array}$ & $\begin{array}{l}\text { Signposting to other sources of } \\
\text { information and support } \\
\text { Dashboards that offer solutions to } \\
\text { be adopted }\end{array}$ & $\mathrm{n} / \mathrm{a}$ & $\begin{array}{l}\text { Links to other } \\
\text { guidance good, } \\
\text { if well chosen }\end{array}$ & $\mathrm{n} / \mathrm{a}$ & $\begin{array}{l}\text { Agreement } \\
\text { from two } \\
\text { sources }\end{array}$ \\
\hline & $\begin{array}{l}\text { Adding } \\
\text { more data }\end{array}$ & $\mathrm{n} / \mathrm{a}$ & User input possible & $n / a$ & $\begin{array}{l}\text { Upload own data (but } \\
\text { predictive capability } \\
\text { relatively unimportant) }\end{array}$ & $\begin{array}{l}\text { Agreement } \\
\text { from two } \\
\text { sources }\end{array}$ \\
\hline
\end{tabular}

Management (CeHRes) [20] for end-to-end design, development and implementation of health informatics technologies.

There is nothing particular about a healthcare dashboard that would make it a specific candidate for the use of DCE in the way we have described per se, but healthcare dashboards have types of data, uses and historical contexts that make their attributes different to those of other dashboards. Thus our use of DCE can be generalised beyond healthcare but the data from our study are only potentially generalisable to other healthcare management dashboards.

While the DCE proved useful in helping the developers decide on the core features for the PRESENT dashboard, extrapolating actual market demand from the experimental findings should be treated with caution for various reasons. First, while a response rate cannot be calculated in online questionnaires, we have a moderate retention rate of about $20 \%$. It is unknown whether those who logged into the questionnaire but did not complete did not do so because they were not interested in the product, not interested in participating or not able to devote the required time, or for some other reason. At the same time, our sample is small, potentially affecting generalisability of preferences and findings. Second, we included snowball sampling with people who had taken part in the study, who may have been biased in favour of the dashboard; however, the nature of the DCE and the large number of invitations sent to other relevant people through professional organisations mean this bias is diluted. Nonetheless, it is not clear what the uptake would be among the overall stakeholder population. Third, while we made every effort to appear realistic in the way we presented the dashboard and its features to participants, the DCE itself and the purchasing behaviour is of a hypothetical nature, where individuals express intentions. There is some literature to suggest that discrepancies between stated and actual behaviours are not uncommon [21] and DCE results are to be verified and further replicated before generalisations can be made. Fourth, in general individuals are assumed throughout to be perfect information processors, although this is not always the case $[22,23]$. Moreover, the problems of potential inconsistency of the respondents' answers to the hypothetical situations increase with the size of the experiment and the difficulty of the tasks [24, 25]. Often individuals find answering the necessary questions increasingly difficult, while fatigue also sets in [26]. These problems could inhibit individuals from using compensatory behaviour (trading off one attribute for another), and instead lead them to either answer at random or use other types of non-compensatory techniques, which could result in lack of robustness in the results [22, 27].

Overall, with these concerns in mind, and with a few further assumptions, a basic evaluation exercise suggests that the development of the online dashboard and its roll-out in the market would result in a positive net benefit and suggests which features are the most important to develop in such a dashboard. We should highlight that this cost-benefit analysis offers a lower bound estimate of the net benefit as it does not acknowledge or incorporate any of the non-monetary benefits that would result from the use of the online dashboard and from which the main benefits are expected to arise (i.e. improved healthcare services, improved health outcomes, enhanced data availability and research etc.). However, given that such evaluation is outside the scope of this project, this would have to be explored in future research. 


\section{Conclusion}

DCEs can be successfully used to inform development of an online dashboard by determining preferences for particular features and customisation options and how this affects individuals' purchasing behaviours. This provides an objective way of determining preferred technology features that is based on access to subconscious cognitive processes. The approach should be transferable to the development of other technologies.

\section{Supplementary information}

Supplementary information accompanies this paper at https://doi.org/10. 1186/s12911-020-1098-z.

Additional file 1. The final list of attributes and levels selected for the DCE.

\section{Abbreviations}

CPES: National Cancer Patient Experience Survey; CeHRes: Centre for eHealth Research and Disease Management; CL: Conditional logit; DCE: Discrete Choice Experiment; MRS: Marginal rates of substitution; NHS: National Health Service (UK); NL: Nested logit model; NRES: National Research Ethics Committee; p.p.: Percentage points; UK: United Kingdom; WTP: Willingnessto-pay

\section{Acknowledgements}

This report presents independent research commissioned by the NIHR (see https://www.journalslibrary.nihr.ac.uk/hsdr/hsdr07230\#/abstract). The views expressed herein are those of the author(s) and not necessarily those of the $\mathrm{NHS}$, the National Institute for Health Research or the Department of Health. Figures and tables are reproduced under the UK government's noncommercial licence for public sector information.

\section{Authors' contributions}

CR had the idea for the main study and was the study lead and grant holder. CR developed the DCE approach with EM. DT assisted with development of the attributes list, piloted and implemented the DCE. EM conceived the precise approach used, led on the development and design of the questionnaire and undertook the analysis. EM was also the lead author and wrote the majority of the first draft text. CR and DT contributed sections of the original draft and all authors edited and refined the manuscript. All authors have read and approved the manuscript.

\section{Funding}

This report presents independent research commissioned and funded by the NIHR (see https://www.journalslibrary.nihr.ac.uk/hsdr/hsdr07230\#/abstract, Health Services and Delivery Research, 14/156/15 - PRESENT: Patient Reported Experience Survey Engineering of Natural Text: developing practical automated analysis and dashboard representations of cancer survey free-text answers). The views expressed herein are those of the author(s) and not necessarily those of the NHS, the National Institute for Health Research or the Department of Health. Figures and tables are reproduced under the UK government's non-commercial licence for public sector information.

\section{Availability of data and materials}

These may be obtained from the corresponding author on request.

\section{Ethics approval and consent to participate}

Research was undertaken in compliance with the Helsinki Declaration (http:// www.wma.net/en/30publications/10policies/b3/index.html). Ethics approval was obtained from an NHS National Research Ethics Committee (NRES 15/ NS/0104) and the study was sponsored by the University of Southampton. Full informed consent was obtained from all participants, online, before the questionnaire itself could be attempted. This included consent for publication of results; no personally identifiable data or quotes are used.

\section{Consent for publication}

Not applicable.

\section{Competing interests}

We have none to declare.

\section{Author details}

${ }^{1}$ Economics Department, School of Social Sciences, University of

Southampton, Southampton, UK. ${ }^{2}$ Faculty of Health Sciences, University of

Southampton, Southampton, UK. ${ }^{3}$ Social Science Research Unit, Department of Social Science, University College London (UCL), 18 Woburn Square, London WC1H ONR, UK.

Received: 3 August 2018 Accepted: 22 April 2020

Published online: 24 May 2020

\section{References}

1. Rivas C, Tkacz D, Antao L, Mentzakis E, Gordon M, Anstee S, Giordano R. Practical automated analysis and dashboard representations of cancer survey free-text answers PRESENT: Patient Reported Experience Survey Engineering of Natural Text: NETSCC; 2019. Report. Southampton: Health Service Delivery Research. https://www.journalslibrary.nihr.ac.uk/HSDR/\#/.

2. Budach G. Part of the puzzle: the retrospective interview as reflexive practice in ethnographic collaborative research. In: Gardner S, Martin-Jones M, editors. Multilingualism, discourse and ethnography. (Routledge critical studies in multilingualism). Abingdon: GB. Routledge; 2012. p. 319-33.

3. Lancaster KJ. A new approach to consumer theory. J Polit Econ. 1966;74(2): 132-57.

4. Rosen S. Hedonic prices and implicit markets: product differentiation in pure competition. J Polit Econ. 1974;82(1):34-55. https://doi.org/10.1086/ 260169

5. Louviere JJ, Hensher DA, Swait JD, Adamowicz W. Stated choice methods: analysis and applications. Cambridge: Cambridge University Press; 2000. ISBN:978-0-521-78830-4.

6. Bateman IJ, Carson RT, Day B, Hanemann M, Hanleys N, Hett T, Jones-Lee M, Loomes G, Mourato S, Ozdemiroglu E, Pearce D, Sugden R, Swanson J. Economic valuation with stated preference techniques: a manual [Internet]. Bateman IJ, editor. Cheltenham: Edward Elgar; 2002. [cited 2018 Apr 17]. Available from: http://www.e-elgar.co.uk/ISBN:978-1-84064-919-2. https:// www.jmp.com/support/notes/35/282.html.

7. Ryan M, Gerard K, Amaya-Amaya M, editors. Using discrete choice experiments to value health and health care [Internet]. Netherlands: Springer; 2008. [cited 2018 Apr 17]. Available from: //www.springer.com/gb/ book/9781402040825ISBN:978-1-4020-4082-5.

8. de Bekker-Grob EW, Ryan M, Gerard K. Discrete choice experiments in health economics: a review of the literature. Health Econ. 2012;21:145-72. https://doi.org/10.1002/hec.1697.

9. Ryan M. Discrete choice experiments in health care. BMJ. 2004;328(7436): 360-1.

10. La Grouw G. Effective dashboard design: design secrets to getting more value from performance dashboards. New Zealand: Electrosmart; 2012.

11. Dowding D, Randell R, Gardner P, et al. Dashboards for improving patient care: review of the literature. Int J Med Inform. 2015;84(2):87-100.

12. Maynard D, Roberts I, Greenwood MA, Rout D, Bontcheva K. A framework for real-time semantic social media analysis. Web Semantics: Science, Services and Agents on the World Wide Web. 2017.

13. Huber J, Zwerina K. The importance of utility balance in efficient choice designs. J Mark Res. 1996:33:307-17. https://doi.org/10.2307/3152127.

14. Zwerina K, Huber J, Kuhfeld WF. A general method for constructing efficient choice designs. Durham: Fuqua School of Business - Duke University; 1996.

15. Gerhardt-Powals J. Cognitive engineering principles for enhancing human computer performance. Int J Hum Comput Interact. 1996;8(2):189-211. https://doi.org/10.1080/10447319609526147 15.

16. JMP Version 12. Cary: SAS Institute Inc.; 1989.

17. McFadden D. Conditional logit analysis of qualitative choice behavior. In: Zarembka P, editor. Front Econom. New York: Academic Press; 1973. p. 10542.

18. Ryan M, Skåtun D. Modelling non-demanders in choice experiments. Health Econ. 2004:13(4):397-402 PMID: 15067675

19. Nielsen J. Designing web usability. Indianapolis: New Riders; 2000. 
20. van Gemert-Pijnen JE, Nijland N, van Limburg M, Ossebaard HC, Kelders SM, Eysenbach G, Seydel ER. A holistic framework to improve the uptake and impact of eHealth technologies. J Med Internet Res. 2011;13(4):e111.

21. Lambooij MS, Harmsen IA, Veldwijk J, de Melker H, Mollema L, van Weert YW, de Wit GA. Consistency between stated and revealed preferences: a discrete choice experiment and a behavioural experiment on vaccination behaviour compared. BMC Med Res Methodol. 2015;15:19 PMID: 25887890. [cited 2018 Apr 17].

22. Swait J. A non-compensatory choice model incorporating attribute cutoffs. Transp Res Part B Methodol. 2001;35(10):903-28.

23. de Palma A, Myers GM, Papageorgiou YY. Rational choice under an imperfect ability to choose. Am Econ Rev. 1994;84(3):419-40.

24. Swait J, Adamowicz W. The influence of task complexity on consumer choice: a latent class model of decision strategy switching. J Consum Res. 2001;28(1):135-48. https://doi.org/10.1086/321952.

25. DeShazo JR, Fermo G. Designing choice sets for stated preference methods: the effects of complexity on choice consistency. J Environ Econ Manag. 2002;44(1):123-43.

26. Swait J, Adamowicz W. Choice environment, market complexity, and consumer behavior: a theoretical and empirical approach for incorporating decision complexity into models of consumer choice. Organ Behav Hum Decis Process. 2001;86(2):141-67. https://doi.org/10.1006/obhd.2000.2941.

27. Elrod T, Johnson RD, White J. A new integrated model of noncompensatory and compensatory decision strategies. Organ Behav Hum Decis Process. 2004;95(1):1-19. https://doi.org/10.1016/j.obhdp.2004.06.002.

\section{Publisher's Note}

Springer Nature remains neutral with regard to jurisdictional claims in published maps and institutional affiliations.

Ready to submit your research? Choose BMC and benefit from:

- fast, convenient online submission

- thorough peer review by experienced researchers in your field

- rapid publication on acceptance

- support for research data, including large and complex data types

- gold Open Access which fosters wider collaboration and increased citations

- maximum visibility for your research: over $100 \mathrm{M}$ website views per year

At $\mathrm{BMC}$, research is always in progress.

Learn more biomedcentral.com/submissions 